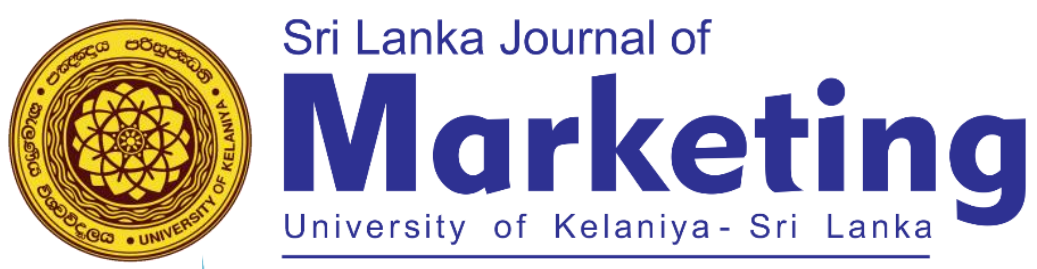

\title{
A Review on E-Banking Adoption in the Context of E-Service Quality
}

\author{
Gayan Nayanajith, D. A. \\ Doctoral Student, University of Kelaniya, Sri Lanka \\ dagnsrilanka@gmail.com \\ Weerasiri, R. A. S. \\ Senior Lecturer, University of Kelaniya, Sri Lanka \\ Damunupola, K.A. \\ Senior Lecturer, Uwa Wellassa University, Sri Lanka
}

\section{ABSTRACT}

Fast-paced expansion of information and communication technology (ICT) revolutionizes different facets of contemporary human life and global economic landscape to a greater extent. Within technological transformation arena, retail financial services which includes retail banking activities performs a pivotal role. Technological advancement and internet facilities have demanded rapid changes radically in the financial services sector service delivery. E-banking facilitates bank customers to engage in an array of banking services via banks' official websites. Amidst these changes e-banking adoption has gained limelight as a researchable notion owing to challenges attributed in different markets and country contexts. This article review founded on the concept of e-banking adaption in line with theoretic and empirical discussions. Hence, literature review was exploited as the main research tool. Research paper attempted to introduce practice related insights by discussing cases that were found within the domain of e-banking adoption. Article is organized as a concept paper to emphasize some of the case evidences with special reference to consumer electronic banking whilst arguments have been supported empirically. Importance of customer awareness, innovativeness, service quality, trust and security aspects related to e-services and prioritizing of marketing to motivate adoption of e-banking solutions has been unveiled by the discussions. In conclusion, paper postulates directions for the future researches in line with empirical justifications.

Keywords: E-banking, E-banking adoption, Financial services, ICT, Service quality, Sri Lanka 


\section{INTRODUCTION}

E-banking constituted as the electronic delivery of banking services and same has been widely researched in many different market contexts all over the world in recent times (Al-Shbiel \& Ahmad, 2016; Gupta \& Kamilla, 2014; Wu, Jayawardhena \& Hamilton, 2014; Zhou, 2014). E-banking is the execution of both the retail and wholesale banking over the internet medium which involves the individual and corporate client segments in the banking sector (UNCTAD, 2002 as cited by Narware, 2016). Researchers circumscribe electronic banking which is commonly known as internet banking among the customers, as "Internet banking, sometimes called online banking, is an outgrowth of PC banking" (Keivani, Jouzbarkand, Khodadadi \& Sourkouhi, 2012, p.2). Internet banking avails the internet as the delivery channel to conduct regular banking activities including transferring of funds, paying utility bills, viewing current and savings account balances, purchasing financial instruments and certificates of deposits. Therefore, e-banking mechanism is an efficient electronic mode of service delivery that enables banks' customers to access multiple bank accounts with a view to facilitate uninterrupted online banking services, within all 24 hours, all year round continuously. Meihami, Varmaghani and Meihami (2013) noted in the research outcome that by reducing operational costs, banks can altogether improve the overall income generation by adopting electronic banking operations. Sheshunoff (2000) argues that most banks have introduced internet banking to their clients with an endeavor to enhance reach, grab new customers/opportunities for business and to make the exit difficult for the customers due to utilization of an array of facilities. Researcher further declared that internet banking currently considered as a sophisticated delivery channel compared to traditional banking since it is useful as an accepted strategic tool for banks to attract and retain customers. Banks generally utilize the internet banking service in order to uplift and expand the business status with regard to embracing innovation (Yakhlef, 2001). Then again, innovations in banking services comparatively easy to replicate and as a result, it is somewhat difficult to sustain an edge over the rivals (Lymperopoulos \& Chaniotakis, 2005). Chavan (2013) argues specifically that many of the corporate clients and individual customers in part of the developing countries either disbelieve or do not possess the required access to the infrastructure to be competent enough to process electronic payments in their own.

On the other hand, e-service quality (E-SQ) relates to the consumers' overall evaluation/ assessment of the excellence and quality of online service offering in the e-marketplace (Santos, 2003). E-SQ can also be illustrated as the extent to which a web site promotes efficient and effective online shopping, purchasing and delivery aspects of products or services. E-SQ can be described in the facets of functionality and quality of service (Zeithaml, Parasuraman \& Malhotra, 2000). Whilst Lassar, Manolis and Lassar (2005) suggested that type of consumer innovation assist to determine adoption of electronic banking. Ho and Lin (2008) stated that electronic service quality measurement in banking services is 
an area of growing interest to both the researchers and managers alike. In addition, importance performance matrix analysis (IPMA) has exhibited numerous factors in order to determine user's intention with reference to adoption of internet banking (Rahi \& Ghani, 2018).

Although Parasuraman et al. (1988) suggested that service quality consists of five major dimensions, they may vary upon the change of the service settings (Teas, 1993). SERVQUAL was developed primarily in the context of face-to-face encounters. In the modern online environment, different service quality dimensions with new measurement items become relevant (Kalia, 2013). In order to measure electronic service quality on web sites, Parasuraman et al. (2005) created 22 -item scale called E-SQUAL. Zeithaml et al (2002) created a 7-dimesion scale in which, the first four dimensions constitute the core e-SERVQUAL scale whereas the latter 3 come into play only when "online customers have questions or run into problems" (Zeithaml et al, 2002, p366). Although the SERVQUAL instrument has been widely applied in a variety of industry and cross-cultural contexts, there are many criticisms of the approach (Ali \& Rasa, 2017; Alnaser et al., 2017). Francis Buttle (1996) published one of the most comprehensive criticisms of the model of service quality and the associated SERVQUAL instrument in which both operational and theoretical concerns were identified. Some of the more important criticisms include validity, constructs, dimensional instability among other things (Buttle, 1996). The model of service quality has its roots in the expectancy-disconfirmation paradigm that informs customer satisfaction. A number of researchers have argued that the research instrument actually captures satisfaction rather than service quality. Other researchers have questioned the validity of conceptualizing service quality as a gap (Oliver, 2014; Souca, 2011; van Dyke et al., 1997). The model's developers tested and retested the SERVQUAL scale for reliability and validity. However, at the same time, the model's developers recommended that applied use of the instrument should modify or adapt them for specific contexts. Any attempt to adapt or modify the scale will have implications for the validity of items with implications for the validity of the dimensions of reliability, assurance, tangibles, empathy and responsiveness (Smith, 1995).

Hence, this demonstrates the controversy with respect to measurement of service quality in diverse service settings (Agrawal, Tripathi \& Agrawal, 2018). Phenomenon of E-SQ could be visible upon advent of internet and same is recently being extended in the e commerce environment. The E-SQ research area is rich in terms of basic concepts and models, application areas or domains, linkages with consumer satisfaction, loyalty and profitability (Agrawal et al., 2018). Thus, it is obvious that ebanking adoption could be researched along with E-SQ in the sphere of consumer banking service context. 


\subsection{Purpose of the Study}

Considerable research studies available in the sphere of e-banking are predominantly considered the customers' perspective and institutional perspective (Hanafizadeh, Keating \& Khedmatgozar, 2013). Institution/bank perspective primarily concerned with the bank managers' attitudes to overall technology aspects, the strategic value in applying and developing new distribution channels, impediments and challenges in transacting with electronic banking service providers. Bank customers' view point could be further isolated into three groups. The first of these associated with the segmentation of users. The concepts of attitudes and motivations of the technology dependent distribution channels have been frequently used as segmentation determining variables to categorize distinct groups of customers (Machauer \& Morgner, 2001).

Demographic constructs are popular basis for segmentation and comparatively easier to recognize and measure than most other variables (Alwan \& Al-Zubi., 2016). Intended for banking services, four core customer segments exist: the branch segment, the telephone segment, the PC segment and the internet segment. Alongside the widespread use and adoption of the internet, it is suggested the future retail banking structure will consist of a few banks and many banks will rely on the internet as their main distribution channel (Chau \& Ngai., 2010). Similarly, attitudes have affected trust and perceived risk towards e-banking adoption (Safeena et al., 2018). An obstacle to e-banking adoption has been noted as the lack of security and privacy over internet medium. This has caused to view e-banking as a risky undertaking. Perceived trust and perceived risk reduction are critical factors in e-banking since they reduce the social complexity for the internet banking and drive towards achievement of goals and objectives. In contrast, without them, there is a failure in attaining the desired outcomes (Fawzy \& Esawai., 2017).

The second category within the customer perspective; satisfaction and loyalty, focuses on the attitudes of customers those who use electronic banking. Literature pertaining to this area tends to deal with customer attitudes and investigates the contributory factors on customer satisfaction with e-banking services and loyalty compared to other modes of distribution channels or other banks (Pikkarainen, Pikkarainen, Karjaluoto \& Pahnila, 2006; Herington \& Weaven, 2009). The third and last group of research studies focuses primarily on the aspect of e-banking adoption of customers. This branch of studies explores the factors that are contributing to the adoption or non-adoption of online banking services (Hanafizadeh et al., 2013; Nayanajith et al., 2019).

The systematic review of the electronic banking adoption literature demonstrates three leading segments of papers namely; descriptive, relational and comparative. Hernandez and Mazzon (2007) identified two groups of electronic banking adoption researches that are termed as descriptive studies and relational studies. Hanafizadeh et al. (2013) introduced an additional category additionally; comparative 
studies, to capture a class of recent studies which have sought to compare the different approaches related to electronic banking adoption research. In the context of adoption of electronic banking services some of the research authors had used combined approaches. Howcroft, Hamilton and Hewer (2002) identified in a qualitative research with both descriptive and comparative approaches that, excellent service quality is one of the determinant factors in adopting home based banking services in United Kingdom. Several researches highlighted the fact that within Sri Lankan context electronic banking adoption is not at a higher level except for ATM facility usage (Abeyrathna, 2015; Dassanayake, 2011; Kariyawasam \& Jayasiri 2015; Premarathne \& Gunatilake 2016; Suraweera et al., 2011). Whilst several other research scholars argued that even though Sri Lankan customers are aware of electronic banking services adoption of same is at a comparatively low level. Customers in general, used to visit bank counters for a number of transactions despite the fact that they could perform such transactions through internet just by a click in their own (Hettiarachchi 2013). Kumari (2016a) noted that degree utilization of electronic banking facilities is quite less than the potential. Researcher further noted that senior academics prefer traditional way of banking over e-banking (Kumari, 2016b). Nevertheless, Weerasekara and Abeygunawardhana (2011) identified even though the use of internet is thriving in Sri Lanka in a rapid pace, the usage of e-banking is relatively very slow considering the increase of internet user statistics. In contrary, several researchers noted that level of effectiveness of e-banking operations is not at low level; nonetheless, there is room for further improvements in future aiming e-banking customers in Sri Lanka (Arulrajah, 2006; Nayanajith \& Damunupola, 2019a \& 2019b). In terms of banks' standpoint, electronic banking performance is somewhat effective although there is room for improvements in future. The banking regulator's report indicated when technology linked into customer needs along with gaining attraction of popular digitalized alternatives, that results fewer people to visit the banks in person (CBSL, 2017). Digitization is a noted practice and argued empirical research scope in Sri Lanka in terms of challenges and consumer adaptation in different sectors (Rasool \& Dissanayake, 2019). While most of the researchers stated that Sri Lankan electronic banking adoption is not at a higher level, top three systemically important licensed private commercial banks have demonstrated that there is a higher growth in digital service delivery channels, which occasionally reported an exponential growth (Sampath Bank Annual Report 2017; Commercial Bank of Ceylon Annual Report 2017; HNB Annual Report 2017). This denotes significant inconsistencies in practical and theoretical perspectives an overall effectiveness of e-banking. In accordance with some research studies, theoretical justification on e-banking adoption seems arguable as per country specific factors (Al-Shbiel \& Ahmad, 2016; Gupta \& Kamilla, 2014; Wu, Jayawardhena \& Hamilton, 2014; Rahi \& Ghani, 2018; Zhou, 2014; Gayan Nayanajith 2019; Gayan Nayanajith \& Dissanayake, 2019; Gayan Nayanajith \& Damunupola, 2019).

Accordingly, this paper endeavors to discuss the concept of e-banking adoption further, based on literature reviews on empirical content and theoretic explanations whilst paying special attention on Sri 
Lankan context. Author is of the view that this will undoubtedly contributes to overall empirical knowledge and practice related knowledge in line with the explanations presented in the article.

\subsection{Methodology}

Paper follows an approach of deductive research since the discussion/argument is entirely based on current empirical and case related insights. Author utilized journal articles on the subject matter, recently published annual reports of top three private commercial banks in Sri Lanka and banking regulator's reports to review the theories, concepts and applications connected to e-banking adoption. Accordingly, literature review was deployed as the central research tool. Research paper made an effort to discuss cases that were found within the sphere of e-banking adoption to introduce practice-based contemplations for the readers of the paper. Article gives emphasis to some of the case evidences whilst particular reference been given to consumer e-banking in Sri Lanka. The research paper is structured as a concept paper while the arguments have been supported empirically. At the end, paper concludes with the future research directions in e-banking domain in line with the discussions therein.

\section{THEORETICAL REVIEW ON E-BANKING ADOPTION AND ELECTRONIC SERVICE QUALITY}

Although Fishbein and Ajzen established the theory of reasoned action (TRA) to understand health behaviors, theorists proclaimed that TRA could be applied generally in any given context to understand and also to predict human behavior (Fishbein \& Ajzen, 1975). According to Sheppard, Hartwick and Warshaw (1988) behavioral intention could predict the enactment of any voluntary act. According to TRA, the degree of behavioral intention can predict whether or not an individual will perform a particular act, subject to behavioral intention being the same and the behavior is perfectly and properly defined (Sheppard et al.,1988; Fishbean, 1967). Afterwards, the theory of planned behavior (TPB) was proposed by Icek Ajzen in 1985 through his article "From intentions to actions: A theory of planned behavior." Theory was developed from the arguments of TRA. Significant association of attitudes and subjective norms to behavior via behavioral intention has been long-established in many studies (Ajzen, 1975; Fishbein \& Ajzen, 1975; Sheppard et al., 1988). Davis's technology acceptance model-TAM (Davis, 1989; Davis, Bagozzi \& Warshaw, 1989) is the widely applied model to explain users' acceptance and usage of technology (Venkatesh, 2000). This model replaces most of TRA's attitude measures by means of the two technology acceptance measures-ease of use and usefulness.

Preceding researches on the diffusion of innovations also advocated a prominent role for perceived ease of use which covers wide array of e-services (Nayanajith et al., 2019b \& 2019c). Tornatzky and Klein (1982) analyzed the technology adoption and found that compatibility, relative advantage, and complexity had the most noteworthy relationships with adoption across a broad range of innovations. 
Legris, Ingham and Collerette (2003) supposed that TAM must be expanded to inculcate variables that account for change processes and that this could be accomplished through entwining of the innovation model into TAM. Numerous researchers have replicated Davis's original work (Davis, 1989) to provide empirical evidence in determining relationships that exist between usefulness, ease of use and system use (Adams, Nelson \& Todd 1992; Davis, 1989; Hendrickson, Massey \& Cronan 1993; Segars \& Grover 1993; Subramanian, 1994; Szajna, 1994). Innovation has been explained as an idea, practice or object that is supposed as novel by an individual or other unit of adoption (Rogers, 1995). Moore and Benbasat (1991) identified eight perceived features of innovation factors that influence the diffusion of an innovation which are namely; relative advantage, compatibility, ease of use, result demonstrability, image, visibility, trialability and voluntariness. Rogers (1983) argued that diffusion is the process by which an innovation is transferred over time among social system's participants. The origins of the theory of diffusion of innovations are diverse and span across multiple disciplines. Rogers (1983) proposed that four main constituents influence the spread of a new idea: the innovation, communication channels, time and a social system. However, some researchers have used unified theory of acceptance and use of technology model which is based on the synthesis of theories of individual acceptance (Venkatesh, Morris, Davis \& Davis, 2003).

Venkatesh et al. (2003) proposed the unified theory of acceptance and use of technology (UTAUT) which is a technology acceptance and usage explanation model articulated by the researchers in their scholarly study of "User acceptance of information technology: Toward a unified view". The UTAUT aims to explicate users' intentions to use an information system (IS) and subsequent usage behavior of same. The theory has been developed upon four key constructs, namely: 1) performance expectancy, 2) effort expectancy, 3) social influence, and lastly 4) facilitating conditions (Venkatesh et al., 2003). The first three constructs are direct determinants of usage on intention and the behavior whilst the fourth is a direct determining factor of user behavior. Gender of the users, age, experience and voluntarism of use are postulated to moderate the effect of the four key constructs on intention of usage and behavior. The theory was advanced through a review and amalgamation/consolidation of the constructs of eight previous models that earlier researchers had deployed to explain IS usage and behavior (TRA, TAM, motivational model, TPB, a combined theory of TPB/TAM models, model of personal computer use, diffusion of innovation theory and social cognitive theory). Successive validation of UTAUT by Venkatesh et al. (2003) in a longitudinal research study found that it explains about $70 \%$ of the variance in behavioral intention to use (BI) and accounts about 50\% in actual usage.

Several measures of e-service quality (E-SQ) are described by Zeithaml, Parasuraman and Malhotra (2002) as being 'ad-hoc'. These constructs, which have attempted to assess E-SQ essentially in terms of the design and quality of websites, include elements that induce satisfaction with a website and/or repeat visits to same (Alpar, 2001; Muylle, Moenaert \& Despontin, 1999: Rice, 1997; Szymanski \& 
Hise, 2000). In this regard, Alpar (2001) identified four attributes of satisfaction with a website that is ease of use and other measures. Liu and Arnett (2000) suggested that determinants of website success include the information and service quality and several other inter-linked facts. Besides the ad-hoc use of website parameters other authors attempt to advance more direct and comprehensive measures of the construct of e-service quality (Ladhari, 2010). Another researcher (Gefen, 2002) modified and replicated the well-known 'SERVQUAL' scale (Parasuraman, Zeithaml \& Berry, 1988; Parasuraman, Berry \& Zeithaml, 1991), whereas others develop their own scales to measure the constructs (Ho \& Lee, 2007; Parasuraman, Zeithaml \& Malhotra, 2005). According to Parasuraman et al. (1991, p.445), "SERVQUAL is a generic instrument with good reliability and validity and broad applicability'. On top of that Parasuraman et al. (1988) establish that consumers evaluate perceived service quality in terms of five dimensions. Traditional service and internet service are significantly different mostly due to the occasional interactions between the service providers and customers during online service experiences (Zeithaml et al., 2000). As a result of severe competition, mere web presence and offering lower prices are simple survival conditions which are not sufficient (Lee \& Lin, 2005; Jun, Yang \& Kim, 2004). E-service quality measurements incorporate additional variables without limiting to variables suchlike reliability, responsiveness and etc. for predicting the success of online business operations (Parasuraman \& Zinkhan, 2002).

Internet has impressively facilitated comparison of the prices and products, which makes it easier for clients to make informed decisions. This has also turned the consumer more demanding and conscious; consumers nowadays exhibit low tolerance for substandard online services. Consequently, providing a superior quality e-service is of prime importance for providers of automated or e-services so as to achieve a competitive advantage (Fassnacht \& Koese, 2006). E-SQ is substantially contributing in accomplishing the business objectives and goals in modern business environment for efficient and enhanced relations with customers whilst attracting large number of customers (Zeithaml et al., 2000, 2002; Yang et al., 2004; Rust \& Lemon, 2001; Keating et al., 2003). Hence, E-SQ is contributing towards attaining business goals and can be recognized as one of the key factors for the success of online service providers, particularly in the banking industry (Agrawal, Tripathi \& Agrawal, 2018).

\subsection{Empirical Review of E-Banking Adoption in the Context of E-Service Quality}

Wang, Wang, Lin and Tang (2003) noted that TAM with an additional variable (along with perceived credibility) has been well applied in the internet-based banking systems and noted that it is quite differentiated from the systems which were examined in previous studies. Additionally, researchers noted that perceived ease of use, perceived usefulness, and perceived credibility to be substantial antecedents of the person's intention to use an internet banking system. Wang et al. (2003) further noted that, individual differentiation variable (computer self-efficacy) was found to be a vital determinant of 
perceived ease of use, perceived usefulness, and perceived credibility of the e-banking. Chan (2006) stated that extended technology acceptance model (TAM2) and social cognitive theory (SCT) have been used to ascertain the factors that would influence the adoption and continuation of internet banking usage. Chau and Lai (2003) worked based on TAM and a research model was generated and empirically tested same with four other additional variables that are theoretically justified as having influence on perceived usefulness and perceived ease of use. Together with that researchers identified that those four variables namely personalization, alliance services, task familiarity, and accessibility found to have a significant influence on perceived usefulness and perceived ease of use, and in turn, found such factors to be more important factors in fostering a positive attitude towards accepting the e-banking services. Altogether, it is noted that the extended TAM has greater explanatory capability (55\%) in explaining attitude towards adoption of internet banking (Chau \& Lai, 2003).

In a research study conducted in Finland in the light of TAM by Pikkarainen et al. (2004) proposed that online banking acceptance can be modeled coupled with the TAM variables perceived usefulness and perceived ease of use (PU \& PEOU) with four other variables referred as perceived enjoyment (PE), information on online banking, security and privacy, and the quality of the internet connection variables as derived from literature. The study conducted by Priyangika, Perera \& Rajapakshe (2016) mainly focused on the analysis of customers' attitude in the direction of internet banking under four factors (TAM with two additional factors); PEOU, PU, perceived risk (PR) and subjective norms (SN). Attitude towards online banking has strong positive interactions with PEOU and PU while PR and the SN have weak positive relationships. Therefore, researchers concluded that licensed commercial banks' customers of Colombo district mostly seek ease and usefulness when adopting electronic banking. Kumari (2016a) identified the factors that affected usage level of e-banking where TAM and perceived risk theory (PRT) models were used to develop the conceptual framework for the study. Some researchers who used extended TAM with moderators indicated that perceived usefulness, perceived ease of use, security, social facet, and the perceived system quality were found to be the most dominant factors explaining the accepting adoption of electronic/internet banking services (Jayasiri, Gunawardana \& Dharmadasa, 2015). Meanwhile, Suraweera et al. (2011) noted that factors identified in the research model combining TAM and information system success model (ISS) are in line with the previous findings. However, since the research presents a model that illustrates the customer reluctance or non-acceptance to use online banking, most factors of TAM and ISS success model have been reversed. Furthermore, several research studies have revealed that PU, PEOU, perceived security and trust of e-services, $\mathrm{SN}$ predictor variables could be used in conjunction with moderators and covariates, in analyzing the e-banking adoption phenomena (Gayan Nayanajith \& Dissanayake, 2019; Gayan Nayanajith \& Damunupola, 2019). 
Yousafzai, Foxall and Pallister (2010) suggested that TAM is superior to both the TRA and TPB in explaining the variance in actual behavior and also in terms of fit of the model in an e-banking context, specifically. TAM outperformed both the TRA and the TPB and explanation could be the TAM's usage of two specific beliefs (PU \& PEOU), which can be applied all across varied kinds of technology acceptance contexts. Structural equation modeling was used in the study to ascertain the extent to which the three models are predictive of consumers' behaviors. Unlike others this study executed in United Kingdom and employed independent measures of actual behavior, as well as behavioral intention. Accordingly, authors noted that TAM is superior to the other two models and clarify the importance of trust in understanding behavior of e-banking. Moreover, as both the TAM and the TPB are advanced theories derived from the TRA, it was anticipated that these two theories would well explain or predict the actual behavior of customers far accurately in comparison to the TRA. Furthermore, e-banking is a technology connected user behavior and the TAM was unambiguously developed to explain such behaviors.

Chiou and Shen (2012) utilized the constructs derived from various sources including the transaction cost analysis (TCA), TAM and relationship marketing literature to develop a framework of determining the precursors of using e-banking. Researchers' findings suggested that in addition to PU and PEOU, customer relationship too has the possibility to alter customers' usage intention for internet banking. Roy, Balaji, Kesharwani and Sekhon (2017) pointed out that TAM and PRT supported for both the extended TAM research model and the hypotheses regarding the relationships between perceived risk, PU, PEOU, attitude, and behavioral intentions of e-banking in Indian context. The research model explained $66 \%$ of variance in behavioral intentions and $60 \%$ of variance in customer attitude directed to internet banking adoption.

Seth, Deshmukh, and Vrat (2005) critically evaluated nineteen service quality models in their review conducted in 2005 for the period in between 1984 to 2003. Researchers mainly focused on the models used to evaluate customer satisfaction in the banking sector such as the service quality model (Parasuraman, Zeithaml \& Berry, 1985), pivotal, core and peripheral (PCP) attribute model (Philip \& Hazlett, 1997), retail service quality and perceived value model (Sweeney, Soutar \& Johnson, 1997), customer value and customer satisfaction model (Oh, 1999), antecedents and mediator model (Dabholkar, David Shepherd \& Thorpe, 2000), internet banking model (Broderick \& Vachirapornpuk, 2002), and the model of e-service quality (Santos, 2003). Ladhari (2010) reviewed research studies which were conducted on measurement scales developed for e-service quality that were published in between 2001 and 2008. Research paper evaluated the methodological challenges in developing E-SQ scales (26 research papers have been considered), which were associated to domains, item generation and purification, data analysis, sampling methods, scale reliability and validity. Subsequently, key dimensions of E-SQ were identified as reliability-fulfillment, ease of use, responsiveness, privacy- 
security, information quality-content and web design. Keskar and Pandey (2018) studied and reviewed research articles in relation to internet banking which were published during 2002 to 2016 with a time span of 15 years. Researchers adopted a multidisciplinary approach, examining literature pertaining to internet banking from various fields such as e-banking, marketing, finance, IT/cyber-security and cloud computing. Further, the study suggested that banks needed to train and assist customers to access internet banking services since such initiatives can generate considerable cost savings for the banks in the long run.

Blut, Chowdhry, Mittal and Brock (2015) conducted a meta-analysis on E-SQ and the results indicated that e-service quality has four underlying dimensions (website design, fulfillment, security/privacy and customer service) although their applicability for overall E-SQ is moderated by country specific (masculinity, power distance, individualism, uncertainty avoidance), regulatory environment specific (financial secrecy and rule of law), and industry specific (services or goods, retailing or banking) factors including the designing of the research. Modeling of E-SQ variables and conceptualization is a prerequisite since that will improve and control the performance of the online service providers while setting priorities in the e-service quality development in a scenario where organizational resources are limited and the market is extremely competitive (Yang, Peterson \& Cai, 2003).

\section{CASE REVIEWS ON E-BANKING ADOPTION}

According to CBSL (2017) when the technology interlinked into customer needs that may unlock prospects that never existed in orthodox banking, leading the banks transforming largely to the digitalized era. While the e-wallets, pre-paid cards, contactless cards, wrist band payments and other digitalized alternatives are rapidly gaining attraction, limited people tend to visit the banks in person. "With continual improvements in technology and consumers' increasing reliance on it, changes to delivery of banking products are likely to happen more efficiently and effectively" (CBSL, 2017). Supportively, Sampath Bank provides practical evidence by experiencing an exponential surge in the usage of all digital channels all over the country, in general. Predominantly, usage volumes in the provinces of North and East have risen sharply over the past two years in response to a project that incorporated a trilingual option across all our digital channels to facilitate even greater customer convenience (Sampath Bank PLC Annual Report, 2017).

In contrast, some research studies highlighted that electronic banking embracing is not at high level except for ATM usage in the Sri Lankan context (Abeyrathna, 2015; Dassanayake, 2011; Kariyawasam \& Jayasiri, 2015; Premarathne \& Gunatilake, 2016; Suraweera et al., 2011). Several other researchers argued that even though Sri Lankan customers are aware of e-banking the adoption of the facility is at a low level. Customers used to visit usually the bank counters for various transactions such as account balance inquiries, settling utility bills and etc. even though they could perform such transactions through 
internet just by a click in their own much conveniently (Hettiarachchi, 2013). Additionally, Kumari (2016a) noted that usage level of e-banking facilities is less than the overall expectations. Researcher further noted that senior academics prefer traditional banking (Kumari, 2016b). Whereas Commercial Bank in addition to focusing on being future ready as a bank, concentrated on taking the customers with the bank on this much sought-after e-onboarding journey (Commercial Bank of Ceylon Annual Report, 2017). The bank with the goal of migration of many customers unto online channels, several ambitious online banking drives were conducted at branches during the financial year, resulting in an increase of $22.90 \%$ of internet and mobile banking users. "The Bank's current platform offers SMEs and corporate customers internet banking services but with the new platform to be launched in 2018 they will also be ready to enjoy mobile banking services" (Commercial Bank of Ceylon Annual Report, 2017, p.81).

As per Weerasekara and Abeygunawardhana (2011), although the use of internet facility is overwhelming in Sri Lanka in a rapid pace, the usage of e-banking is comparatively very sluggish as against the increase of number of internet users. Sri Lanka is noted as a context that attributes digital trends in business models but consumer involvement is still to be penetrated (Siriwardane \& Dissanayake, 2018). Thus, overall examination is a must in Sri Lankan context to evaluate the digital business adaptations. However, another researcher noted that effectiveness of the e-banking operation is not at low level; however, there is an opportunity for further improvement. Researcher further noted that, from the banks' perspective electronic banking performance is moderately effective while there is a possibility for improvements in future (Arulrajah, 2006).CBSL (2017) further noted that, remarkable developments observed in technology and payments and settlements infrastructure which could be used by financial service providers as catalysts to deepen the financial market, will assist in achieving substantial financial inclusion, financial system stability as well as the economic development in long run. From a user perspective, the lack of awareness and confidence about existing financial products, specially the innovative new ones, continues to be a major setback for the deepening of the financial market. Dineshwar \& Steven (2013) found that awareness of local mobile banking services is fairly high and usage level is reasonable for Mauritius banking customers. Whilst conflicting with the regulator, another private bank noted "Customer growth continues to be encouraging as we increase our penetration within the country. A key development has been the customer migration to digital platforms taking advantage of the state-of-the-art online banking solution offered...” (HNB Annual Report, 2017). Bigne-Alcaniz, Ruiz-Mafé, Aldás-Manzano, \& Sanz-Blas (2008) in an effort to understand who does and does not use electronic banking systems in Spain, have found that banks which offer services of online banking need to be aware of and appreciate the prominence of internet-specific consumer innovation levels and characteristics. 


\section{CONCLUSION AND FURTHER RESEARCH DIRECTIONS}

Researcher suggested that in order to increase the extent of usage, customer awareness must be increased by taking into account of the details of the e-banking facilities together with their embedded advantages (Rajapakse, 2017). However, creating the e-banking interface striking and easier to navigate is not enough to increase the adoption rate of e-banking (Jayasiri et al., 2016). Trust building activities to avoid distrust and to diminish perceived risk must be continuously pursued (Al-Samadi, 2012; Hettiarachchi, 2013; Kolodinsky, 2004; Lichtenstein \& Williamson, 2006; Grabner-Kräuter \& Faullant, 2008; Khraim, 2011). In the marketing process of internet banking services, marketing experts should emphasize the array of benefits in adoption and customer awareness can be improved to attract consumers' attention to e-banking services (Kariyawasam \& Jayasiri, 2016; Premarathne \& Gunathilleke 2016). Innovativeness coupled with e-service quality should be utilized to increase the use of electronic banking among actual customers who are still non- users or light users of the electronic channel (Bigne-Alcaniz et al., 2008; Daniel, 1999; Rogers, 2003; Suraweera, 2011; Gayan Nayanajith \& Dissanayake, 2019). Thus, author highlights e-banking adaptation is still found to be a desired research notion as per different country perspectives and consumer profiles.

Given the future research aspect, bank customers' perspective related customer segmentation could be further researched. The concepts of attitudes and motivations regarding the technology dependent distribution channels are frequently used as segmentation variables to classify distinct clusters of customers (Machauer \& Morgner, 2001). Investigations on customer attitudes and factors contributing to customer satisfaction with regards to e-banking services and customer loyalty are empirically indicated for future studies (Herington \& Weaven, 2009; Pikkarainen et al., 2006; Premarathne \& Gunathilleke, 2016). In the meantime, researcher suggests researches on institutional perspectives which is a comparatively less studied branch of e-banking studies. Hernandez and Mazzon (2007) and Hanafizadeh et al. (2013) postulated research directions on e-banking adaptation mentioning options for framing such empirical studies. As per the explanations provided in this paper, e-service quality could be examined simultaneously with the adoption of e-banking. Specific research interests are encouraged to examine e-banking adoption using different adoption models including trust, perceived risk, online security, ease of use and usefulness of services as connective concepts. Sri Lankan banking and financial sector needs comprehensive studies to investigate how consumers become more connected to adopt e-banking services. 


\section{REFERENCES}

[1] Abeyrathna, B. G. C. M. (2015). A Study on the Nature of the Customers Who Used IT Driven Banking Services of Commercial Banks. In Peradeniya Economics Research Symposium 2015.

[2] Adams, D. A., Nelson, R. R., \& Todd, P. A. (1992). Perceived usefulness, ease of use, and usage of information technology: A replication. MIS Quarterly, 227-247.

[3] Agrawal, V., Tripathi, V., \& Agrawal, A. M. (2018). Exploring key dimensions of e-service quality: a case of Indian banking industry. International Journal of Services and Operations Management, 29(2), 252-272.

[4] Ajzen, I. (1985). From intentions to actions: A theory of planned behavior. In Action control (pp. 11-39). Springer, Berlin, Heidelberg.

[5] Ali, M., \& Raza, S. A. (2017). Service quality perception and customer satisfaction in Islamic banks of Pakistan: the modified SERVQUAL model. Total Quality Management \& Business Excellence, 28(5-6), 559-577.

[6] Alnaser, F., Ghani, M., \& Rahi, S. (2017). The Impact of SERVQUAL Model and Subjective Norms on Customer's Satisfaction and Customer Loyalty in Islamic Banks: A Cultural Context. Int J Econ Manag Sci, 6(5), 455.

[7] Alwan, H. A., \& Al-Zubi, A. I. (2016). Determinants of internet banking adoption among customers of commercial banks: an empirical study in the Jordanian banking sector. international journal of business and management, 11(3), 95.

[8] Alpar, P. (2001). Satisfaction with a web site: Its measurement, factors (No. 99/01). and correlates. Working Paper.

[9] Al-Shbiel, S. and Ahmad, M. (2016). A Theoretical Discussion of Electronic Banking in Jordan by Integrating Technology Acceptance Model and Theory of Planned Behavior. International Journal of Academic Research in Accounting, Finance and Management Sciences, 6, 272-284.

[10] Arulrajah, A. A. (2006). An Investigation into the Effectiveness of E-Banking in Sri Lanka. Unpublished Master's.

[11] Bigne-Alcaniz, E., Ruiz-Mafé, C., Aldás-Manzano, J., \& Sanz-Blas, S. (2008). Influence of online shopping information dependency and innovativeness on internet shopping adoption. Online Information Review, 32(5), 648-667. 
[12] Blut, M., Chowdhry, N., Mittal, V., \& Brock, C. (2015). E-service quality: A meta-analytic review. Journal of Retailing, 91(4), 679-700.

[13] Broderick, A. J., \& Vachirapornpuk, S. (2002). Service quality in internet banking: the importance of customer role. Marketing Intelligence \& Planning, 20(6), 327-335.

[14] Buttle, F. (1996). SERVQUAL: review, critique, research agenda. European Journal of marketing, 30(1), 8-32.

[15] Central Bank of Sri Lanka 2017 Annual Report 2017, Sri Lanka: Central Bank of Sri Lanka.

[16] Chan, S. C. (2006). Understanding Internet Banking Adoption and Use Behavior: A Hong Kong Perspective.

[17] Chau, P. Y., \& Lai, V. S. (2003). An empirical investigation of the determinants of user acceptance of internet banking. Journal of Organizational Computing and Electronic Commerce, 13(2), 123 145.

[18] Chavan, J. (2013). Internet banking-Benefits and challenges in an emerging economy. International Journal of Research in Business Management, 1(1), 19-26.

[19] Chiou, J. S., \& Shen, C. C. (2012). The antecedents of online financial service adoption: the impact of physical banking services on Internet banking acceptance. Behavior \& Information Technology, 31(9), 859-871.

[20] Commercial Bank of Ceylon PLC 2018, Annual Report 2017

[21] Dabholkar, P. A., Shepherd, C. D., \& Thorpe, D. I. (2000). A comprehensive framework for service quality: an investigation of critical conceptual and measurement issues through a longitudinal study. Journal of retailing, 76(2), 139-173.

[22] Dassanayake, D. D. (2011). Critical factors influencing the selection and continued usage of internet banking in Sri Lanka.

[23] Davis, F. D. (1989). Perceived usefulness, perceived ease of use, and user acceptance of information technology. MIS Quarterly, 319-340.

[24] Davis, F. D., Bagozzi, R. P., \& Warshaw, P. R. (1989). User acceptance of computer technology: a comparison of two theoretical models. Management Science, 35(8), 982-1003. 
[25] Dineshwar, R., \& Steven, M. (2013, February). An investigation on mobile banking adoption and usage: A case study of Mauritius. In Proceedings of 3rd Asia-Pacific Business Research Conference (Vol. 3, pp. 1-21).

[26] Fassnacht, M., \& Koese, I. (2006). Quality of electronic services: conceptualizing and testing a hierarchical model. Journal of service research, 9(1), 19-37.

[27] Fawzy, S. F., \& Esawai, N. (2017). Internet banking adoption in Egypt: Extending technology acceptance model. Journal of Business and Retail Management Research, 12(1).

[28] Fishbein, M. (1967). A behavior theory approach to the relations between beliefs about an object and the attitude toward the object. In M. Fishbein (Ed.), Readings in attitude theory and measurement (pp. 389-400). New York: John Wiley \& Sons.

[29] Fishbein, Martin, and Icek Ajzen. Belief, Attitude, Intention and Behavior. Addison-Wesley, 1975.

[30] Gayan Nayanajith, D. A. \& Dissanayake, D. M. R. (2019) "E-Banking Adoption in the Context of Innovation and E-Service Quality: A Review on Concepts and Practices", Journal of Environmental Science, Computer Science and Engineering \& Technology, Vol.8 Issue:3, pp.208221, https://doi.org/10.1108/02652320310457776

[31] Gayan Nayanajith, D. A. \& Damunupola, K. A. (2019) "E-Service Trustworthiness and Adoption of Online Banking in the Presence of a Moderator: A Relational Study", Journal of Environmental Science, Computer Science and Engineering \& Technology, Vol.8Issue:4,pp.265-289, DOI: 10.24214/jecet.B.8.4.26589.

[32] Gayan Nayanajith, D.A. (2019). 'Relationship of Innovation Characteristics on Adoption of Consumer E-Banking in the Context of Top Three Private Commercial Banks in Sri Lanka', ICBI 2019, Kelaniya, 17 October, viewed 21 September 2019, http://conf.kln.ac.lk/icbi2019/

[33] Gefen, D. (2002). Reflections on the dimensions of trust and trustworthiness among online consumers. ACM SIGMIS Database: the DATABASE for Advances in Information Systems, 33(3), 38-53.

[34] Gupta, D. and Kamilla, U. (2014). Cyber Banking in India: A Cross-Sectional Analysis Using Structural Equation Model. IUP Journal of Bank Management, 13, 47. 
[35] Hanafizadeh, P., Keating, B. W., \& Khedmatgozar, H. R. (2014). A systematic review of Internet banking adoption. Telematics and Informatics, 31(3), 492-510.

[36] Hatton National Bank PLC (2018). Annual Report 2017

[37] Hendrickson, A. R., Massey, P. D., \& Cronan, T. P. (1993). On the test-retest reliability of perceived usefulness and perceived ease of use scales. MIS Quarterly, 227-230.

[38] Herington, C., \& Weaven, S. (2009). E-retailing by banks: e-service quality and its importance to customer satisfaction. European Journal of Marketing, 43(9/10), 1220-1231.

[39] Hettiarachchi, H. A. H. (2013). Factors affecting to customer adoption in internet banking.

[40] Howcroft, B., Hamilton, R., \& Hewer, P. (2002). Consumer attitude and the usage and adoption of home-based banking in the United Kingdom. International journal of bank marketing, 20(3), 111121.

[41] Jayasiri, N. K., Gunawardana, K., \& Dharmadasa, P. (2015). Adoption of Internet Banking in Sri Lanka: An Extension to Technology Acceptance Model. First Asia Pacific Conference on Contemporary Research

[42] Jun, M., Yang, Z., \& Kim, D. (2004). Customers' perceptions of online retailing service quality and their satisfaction. International Journal of Quality \& Reliability Management, 21(8), 817-840

[43] Kariyawasam, N. J., \& Jayasiri, N. K. (2015). Awareness and Usage of Internet Banking Facilities in Sri Lanka. International Journal of Scientific Research and InnovativeTechnology. ISSN, 23133759.

[44] Kalia, P. (2013). E-SERVQUAL and electronic retailing. In dalam Proceedings of the 3rd National Conference on Trends and Issues in Product and Brand Management (84-87).

[45] Keating, B., Rugimbana, R., \& Quazi, A. (2003). Differentiating between service quality and relationship quality in cyberspace. Managing Service Quality: An International Journal, 13(3), 217232.

[46] Keivani, F. S., Jouzbarkand, M., Khodadadi, M., \& Sourkouhi, Z. K. (2012). A General View on the E-banking. International Proceedings of Economics Development \& Research, 43, p62.

[47] Keskar, M. Y., \& Pandey, N. (2018). Internet banking: a review (2002-2016). Journal of Internet Commerce, 17(3), 310-323. 
[48] Kumari, J. P. (2016a). Conceptual Framework: Factors Affecting for usage of Online Banking in Sri Lanka. International Journal, 25.

[49] Kumari, J. P. (2016b). A Study of Online Banking Usage among University Academics. Social Sciences, 18(18.75), 32.

[50] Ladhari, R. (2010). Developing e-service quality scales: A literature review. Journal of Retailing and Consumer Services, 17(6), 464-477.

[51] Lassar, W. M., Manolis, C., \& Lassar, S. S. (2005). The relationship between consumer innovativeness, personal characteristics, and online banking adoption. International Journal of Bank Marketing, 23(2), 176-199.

[52] Lee, G. G., \& Lin, H. F. (2005). Customer perceptions of e-service quality in online shopping. International Journal of Retail \& Distribution Management, 33(2), 161-176.

[53] Legris, P., Ingham, J., \& Collerette, P. (2003). Why do people use information technology? A critical review of the technology acceptance model. Information \& Management, 40(3), 191-204.

[54] Liu, C., \& Arnett, K. P. (2000). Exploring the factors associated with Web site success in the context of electronic commerce. Information \& Management, 38(1), 23-33.

[55] Lymperopoulos, C., \& Chaniotakis, I. E. (2005). Factors affecting acceptance of the internet as a marketing-intelligence tool among employees of Greek bank branches. International Journal of Bank Marketing, 23(6), 484-505.

[56] Machauer, A., \& Morgner, S. (2001). Segmentation of bank customers by expected benefits and attitudes. International Journal of Bank Marketing, 19(1), 6-18.

[57] Mauro C. Hernandez, J., \& Afonso Mazzon, J. (2007). Adoption of internet banking: proposition and implementation of an integrated methodology approach. International Journal of Bank Marketing, 25(2), 72-88

[58] Meihami, B., Varmaghani, Z., \& Meihami, H. (2013). The effect of using electronic banking on profitability of bank. Interdisciplinary Journal of Contemporary Research in Business, 4(12), 1299131.

[59] Moore, G. C., \& Benbasat, I. (1991). Development of an instrument to measure the perceptions of adopting an information technology innovation. Information Systems Research, 2(3), 192-222. 
[60] Muylle, S., Moenaert, R., \& Despontin, M. (1999). Measuring web site success: An introduction to web site user satisfaction. In American Marketing Association. Conference Proceedings (Vol. 10, p. 176). American Marketing Association.

[61] Narware, D. P. (2016). E-banking-challenges \& policy implications.

[62] Nayanajith, G., \& Damunupola, K. A. (2019a). Effects of Subjective Norms and Security on Online Banking Adoption: Multilevel Linear Model Analysis. Asian Journal of Multidisciplinary Studies, 2(1).

[63] Nayanajith, G., \& Damunupola, K. A. (2019b). Relationship of Perceived Behavioral Control and Adoption of Internet Banking in the Presence of a Moderator. Asian Journal of Multidisciplinary Studies, 2(2).

[64] Nayanajith, G., Damunupola, K. A., \& Ventayen, R. J. (2019a). User Intentions and Actio Towards Adoption of Technology Based Self-Service Banking Services: A MANOVA Analysis. Southeast Asian Journal of Science and Technology, 4(1).

[65] Nayanajith, G., Damunupola, K. A., \& Ventayen, R. J. (2019c). Impact of Innovation and Perceived Ease of Use on E-Learning Adoption. Asian Journal of Business and Technology, 2(1).

[66] Oh, H. (1999). Service quality, customer satisfaction, and customer value: A holistic perspective. International Journal of Hospitality Management, 18(1), 67-82.

[67] Oliver, R. L. (2014). Satisfaction: A behavioral perspective on the consumer: A behavioral perspective on the consumer. Routledge.

[68] Parasuraman, A., \& Zinkhan, G. M. (2002). Marketing to and serving customers through the Internet: An overview and research agenda. Journal of the academy of marketing science, 30(4), 286-295.

[69] Parasuraman, A., Berry, L. L., \& Zeithaml, V. A. (1991). Refinement and reassessment of the SERVQUAL scale. Journal of Retailing, 67(4), 420.

[70] Parasuraman, A., Zeithaml, V. A., \& Berry, L. L. (1985). A conceptual model of service quality and its implications for future research. Journal of marketing, 49(4), 41-50.

[71] Parasuraman, A., Zeithaml, V. A., \& Berry, L. L. (1988). Servqual: A multiple-item scale for measuring consumer perc. Journal of Retailing, 64(1), 12 
[72] Parasuraman, A., Zeithaml, V. A., \& Malhotra, A. (2005). ES-QUAL: a multiple-item scale for assessing electronic service quality, Journal of Service Research, 7(3), 213-233.

[73] Philip, G. \& Hazlett, S. A. (1997). The measurement of service quality: a new PCP attributes model. International Journal of Quality \& Reliability Management, 14(3), 260-286.

[74] Pikkarainen, T., Pikkarainen, K., Karjaluoto, H., \& Pahnila, S. (2004). Consumer acceptance of online banking: an extension of the technology acceptance model. Internet Research, 14(3), 224235.

[75] Premarathne, W., and M. M. Gunatilake. (2016); Consumer adoption of internet banking in Sri Lanka Int. J. of Adv. Res. 4 (11). 758-765] (ISSN 2320-5407).

[76] Priyangika, R. D., Perera, M. S. S., \& Rajapakshe, D. P. (2016). An Empirical Investigation on Customer Attitude and Intention towards Internet Banking: A Case of Licensed Commercial Banks in Colombo District, Sri Lanka

[77] Rahi, S., \& Ghani, M. A. (2018). A structural equation modeling (SEM-AMOS) for investigating brand loyalty and customer's intention towards adoption of internet banking. Economic and Social Development: Book of Proceedings, 206-220.

[78] Rajapakse, R. P. C. R. (2017). E-Banking: A Review of Status, Implementation, Challenges and Opportunities. International Journal of Economics, Business and Management Research, 1(05), 386-408.

[79] Rasool, M. P. R. \& Dissanayake, D.M. R. (2019), Digital Transformation for Small and Medium Enterprises (SMES): with Special Focus on Sri Lankan Context as an Emerging Economy. International Journal of Business and Management Review. 7(4), 59 - 76

[80] Rice, M. (1997). What makes users revisit a web site?. Marketing News, 31(6), 12-12.

[81] Rogers. E (1995). Diffusion of Innovations. New York: Free Press.

[82] Rogers, E.M. (1983) Diffusion of Innovations. Free Press, New York.

[83] Roy, S. K., Balaji, M. S., Kesharwani, A., \& Sekhon, H. (2017). Predicting Internet banking adoption in India: A perceived risk perspective. Journal of Strategic Marketing, 25(5-6), 418-438. 
[84] Rust, R. T., \& Lemon, K. N. (2001). E-service and the consumer. International journal of electronic commerce, 5(3), 85-101.

[85] Sampath Bank PLC (2018). Sampath Bank PLC.

[86] Safeena, R., Kammani, A., \& Date, H. (2018). Exploratory study of internet banking technology adoption. In Technology Adoption and Social Issues: Concepts, Methodologies, Tools, and Applications (pp. 333-355). IGI Global.

[87] Santos, J. (2003). E-service quality: a model of virtual service quality dimensions. Managing Service Quality: An International Journal, 13(3), 233-246.

[88] Segars, A. H., \& Grover, V. (1993). Re-examining perceived ease of use and usefulness: A confirmatory factor analysis. MIS quarterly, 517-525.

[89] Seth, N., Deshmukh, S. G., \& Vrat, P. (2005). Service quality models: a review. International journal of quality \& reliability management, 22(9), 913-949

[90] Sheppard, B. H., Hartwick, J., \& Warshaw, P. R. (1988). The theory of reasoned action: A metaanalysis of past research with recommendations for modifications and future research. Journal of consumer research, 15(3), 325-343.

[91] Sheshunoff, A. (2000). Internet banking--An update from the frontlines. American Bankers Association. ABA Banking Journal, 92(1), 51.

[92] Siriwardana \& D.M.R.Dissanayake, Social Customer Relationship Management (SCRM) in Contemporary Business Era, International Journal Business and Management Invention (IJBMI), 2018, 7(9), 59-64

[93] Smith, A. M. (1995). Measuring service quality: is SERVQUAL now redundant? Journal of Marketing Management, 11(1-3), 257-276.

[94] Souca, M. L. (2011). SERVQUAL-Thirty years of research on service quality with implications for customer satisfaction. Marketing From Information to Decision, (4), 420-429.

[95] Subramanian, G. H. (1994). A replication of perceived usefulness and perceived ease of use measurement. Decision sciences, 25(5-6), 863-874. 
[96] Sum Chau, V., \& Ngai, L. W. (2010). The youth market for internet banking services: perceptions, attitude and behaviour. Journal of Services Marketing, 24(1), 42-60.

[97] Suraweera, T., Kahingala, S., Batepola, A., Punchihewa, M., Senevirathna, K., \& Kahandawaarachchi, C. (2011). IT Driven Banking Services in Sri Lanka: Customer Acceptance and Service Quality. Retrieved: November, 4, 2012.

[98] Sweeney, J. C., Soutar, G. N., \& Johnson, L. W. (1997). Retail service quality and perceived value: A comparison of two models. Journal of Retailing and Consumer Services, 4(1), 39-48.

[99] Szajna, B. (1994). Software evaluation and choice: Predictive validation of the technology acceptance instrument. MIS quarterly, 319-324.

[100] Szymanski, D. M., \& Hise, R. T. (2000). E-satisfaction: an initial examination. Journal of retailing, 76(3), 309-322.

[101] Tornatzky, L. G., \& Klein, K. J. (1982). Innovation characteristics and innovation adoptionimplementation: A meta-analysis of findings. IEEE Transactions on engineering management, (1), $28-45$.

[102] UNCTAD (2002). United Nations Conference on Trade and Development, "E-commerce and development Report.

[103] Van Dyke, T. P., Kappelman, L. A., \& Prybutok, V. R. (1997). Measuring information systems service quality: concerns on the use of the SERVQUAL questionnaire. MIS quarterly, 195-208.

[104] Venkatesh, V. (2000). Determinants of perceived ease of use: Integrating control, intrinsic motivation, and emotion into the technology acceptance model. Information systems research, 11(4), 342-365.

[105] Venkatesh, V., \& Davis, F. D. (2000). A theoretical extension of the technology acceptance model: Four longitudinal field studies. Management science, 46(2), 186-204.

[106] Venkatesh, V., Morris, M. G., Davis, G. B., \& Davis, F. D. (2003). User acceptance of information technology: Toward a unified view. MIS quarterly, 425-478.

[107] Wang, Y. S., Wang, Y. M., Lin, H. H., \& Tang, T. I. (2003). Determinants of user acceptance of Internet banking: an empirical study. International journal of service industry management, 14(5), 501-519. 
[108] Weerasekara, S., \& Abeygunawardhana, P. K. W. (2011, August). An empirical study on slow and limited adoption of internet banking by Sri Lankan customers. In Industrial and Information Systems (ICIIS), 2011 6th IEEE International Conference on (pp. 404-409). IEEE.

[109] Wu, M., Jayawardhena, C. and Hamilton, R. (2014). A Comprehensive Examination of Internet Banking User Behaviour: Evidence from Customers Yet to Adopt, Currently Using and Stopped Using. Journal of Marketing, 30, 1006-1038.

[110] Yakhlef, A. (2001). Does the Internet compete with or complement bricks-and-mortar bank branches? International Journal of Retail \& Distribution Management, 29(6), 272-281

[111] Yang, Z., Jun, M., \& Peterson, R. T. (2004). Measuring customer perceived online service quality: scale development and managerial implications. International Journal of Operations \& Production Management, 24(11), 1149-1174.

[112] Yang, Z., Peterson, R. T., \& Cai, S. (2003). Services quality dimensions of Internet retailing: an exploratory analysis. Journal of services marketing, 17(7), 685-700.

[113] Yousafzai, S. Y., Foxall, G. R., \& Pallister, J. G. (2010). Explaining internet banking behavior: theory of reasoned action, theory of planned behavior, or technology acceptance model?. Journal of Applied Social Psychology, 40(5), 1172-1202.

[114] Zeithaml, V. A., Parasuraman, A., \& Malhotra, A. (2000). Conceptual Framework for understanding e-service quality: Implications for future research and managerial practice.

[115] Zeithaml, V. A., Parasuraman, A., \& Malhotra, A. (2002). Service quality delivery through web sites: a critical review of extant knowledge. Journal of the academy of marketing

[116] Zhou, T. (2014). Understanding the Determinants of Mobile Payment Continuance Usage. Industrial Management \& Data Systems, 114, 936-948. https://doi.org/10.1108/IMDS-02-20140068 
